\title{
ENHANCING THE EFFICIENCY OF AN IC ENGINE USING THE CONCEPT OF PREHEATING
}

\author{
R.Vishal ${ }^{1}$ \\ ${ }^{1}$ Student, IV semester, Mechanical Engineering, SASTRA University, Thirumalaisamudram, Thanjavur, Tamil Nadu \\ 613401, India \\ Vishal_jayanthi@yahoo.co.in
}

\begin{abstract}
Today's IC engines have a maximum efficiency of only around 40\%. This is due to a variety of losses which occur in the engine in the form of losses through exhaust, incomplete combustion, frictional losses inside the combustion cylinder, poor mixture of air and fuel inside the cylinder etc. Out of these factors, incomplete combustion contributes to majority of the heat loss. Incomplete combustion may occur mainly due to production of steam in the engine and humidity in the atmosphere because of which the fuel may not burn completely. Incomplete combustion not only reduces engine efficiency, but also releases harmful gases like CO, $\mathrm{CO}_{2}, \mathrm{NO}_{2}$ and $\mathrm{SO}_{2}$ into the atmosphere which lead to devastating environmental phenomenon like green-house effect and global warming. This paper suggests a possible way to reduce exhaust losses through the process of preheating which as a result increases the efficiency of the IC engine a little further.
\end{abstract}

Keywords: IC Engine, Air Preheater, Heat Exchanger, Energy Management

\section{INTRODUCTION}

Fossil fuels have been long used as primary fuels for a variety of activities ranging from combustion in automobile engines to cooking in households. As much as they have served us well over the years, they have also caused a lot of damage to our environment in many ways like rising sea levels as a direct result of melting of polar ice caps, untimely rain, droughts, overall increase in global temperature etc. The gases responsible for the above phenomenon are caused mainly due to incomplete combustion of the fossil fuels that we have been using. India has experienced a dramatic growth in fossil-fuel $\mathrm{CO}_{2}$ emissions from 1950-2008 averaging at around 5.7\% per year ${ }^{[1]}$ making it the world's third largest fossil-fuel $\mathrm{CO}_{2}$ emitting country. The method of preheating not only suggests a way to increase the efficiency of an IC engine but also reduces the exhaust emissions due to incomplete combustion.

\section{WHAT IS AN AIR PREHEATER?}

An air preheater refers to any apparatus which heats air before a secondary process takes place with its main objective being the increase in thermal efficiency. Preheating can be achieved by the use of a heat exchanger [2].

The heat exchanger is made of materials with high thermal conductivity. Materials which are generally used are carbon steel, stainless steel, copper, bronze, brass, aluminum, titanium and other silver alloys ${ }^{[3]}$. The material should not only be cheap but also should be efficient and available quite easily. As heating takes place at inlet, there is a chance of chemical corrosion to occur. Thus, the material should also be inert. Generally, aluminum and titanium alloys are used in preheaters.

\section{CONCEPT OF PREHEATING}

The atmosphere contains around $4.24 \%$ of water vapor ${ }^{[4]}$. Water vapor not only is the

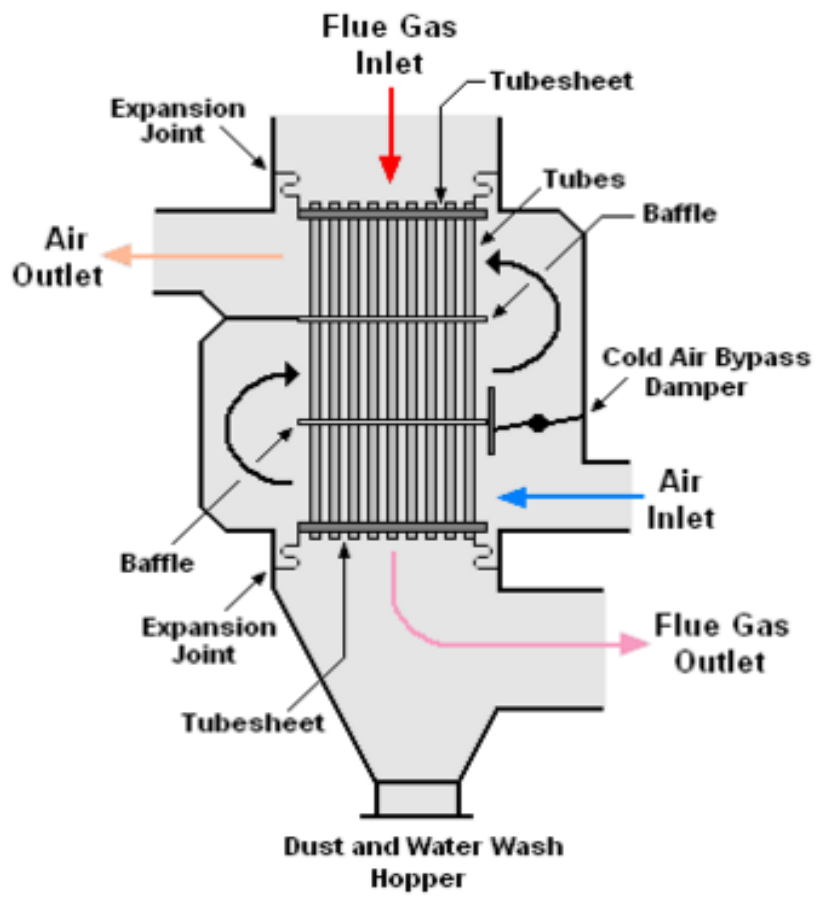

Figure 1. Airpreheater [5]

Source: http://www.ustudy.in/node/7902 
Principle reason for incomplete combustion but also causes the generation of steam inside the combustion cylinder which reduces the overall thermal efficiency of the engine. Steam generation also causes the corrosion of walls of the cylinder which ultimately reduces the durability of the engine.

The concept of preheating is the same for both two wheelers and four wheelers although the setup might change slightly. A heat exchanger is attached at the inlet pipe of the IC engine. The heat from the exhaust gases are absorbed and sent back to the inlet by the heat exchanger. As a result, the air entering the engine is heated and a great deal of water vapor is removed from it which allows the fuel to undergo close to complete combustion which further decreases the emission of harmful effluents. Steam formation during combustion can also be stopped by the removal of water vapor.

\section{EXPERIMENTAL DATA}

An experiment conducted on a Honda Activa engine coupled with an odometer carried out in the laboratory. The test was done using $100 \mathrm{ml}$ of fuel on each turn with increasing speed. The following results were obtained:-

Table 1: Before connecting the heat exchanger

\begin{tabular}{|l|l|l|l|l|l|}
\hline S.No & $\begin{array}{l}\text { Fuel } \\
\text { Used } \\
(\mathrm{ml})\end{array}$ & $\begin{array}{l}\text { Speed } \\
(\mathrm{km} / \mathrm{hr})\end{array}$ & $\begin{array}{l}\text { Distance } \\
(\mathrm{km})\end{array}$ & $\begin{array}{l}\text { Time } \\
(\mathrm{sec})\end{array}$ & Mileage \\
\hline 1 & 100 & 40 & 5.6 & 504 & 56 \\
\hline 2 & 100 & 50 & 5.4 & 388.84 & 54 \\
\hline 3 & 100 & 60 & 5.4 & 324 & 54 \\
\hline 4 & 100 & 70 & 5.5 & 282.86 & 55 \\
\hline & & & & average & 54.75 \\
\hline
\end{tabular}

Table 2: After connecting the heat exchanger

\begin{tabular}{|l|l|l|l|l|l|}
\hline S.No & $\begin{array}{l}\text { Fuel } \\
\text { Used } \\
(\mathrm{ml})\end{array}$ & $\begin{array}{l}\text { Speed } \\
(\mathrm{km} / \mathrm{hr})\end{array}$ & $\begin{array}{l}\text { Distance } \\
(\mathrm{km})\end{array}$ & $\begin{array}{l}\text { Time } \\
(\mathrm{sec})\end{array}$ & Mileage \\
\hline 1 & 100 & 40 & 5.64 & 507.6 & 56.4 \\
\hline 2 & 100 & 50 & 5.58 & 401.76 & 55.8 \\
\hline 3 & 100 & 60 & 5.61 & 336.6 & 56.1 \\
\hline 4 & 100 & 70 & 5.64 & 290.06 & 56.4 \\
\hline & & & & average & 56.175 \\
\hline
\end{tabular}

Note: The fuel used in the above case is petrol. The experiment was carried out at constant speeds. The yielded results may vary under varying speeds.

\section{THE FUTURE TRENDS}

According to an article published by The New York Times, the global economy in 2050 will be approximately 4 times as that of the current economy and the energy consumption rate will be around $80 \%$ more. It also stated that fossil fuels will make up approximately $85 \%$ of the energy sources which will lead to a complete depletion in fossil fuel reserves. As a result, the $\mathrm{CO}_{2}$ emissions are expected to increase by around $70 \%$ which will drive average global temperature up by around 3 to $6^{\circ} \mathrm{C}$ by $2100^{[6]}$.

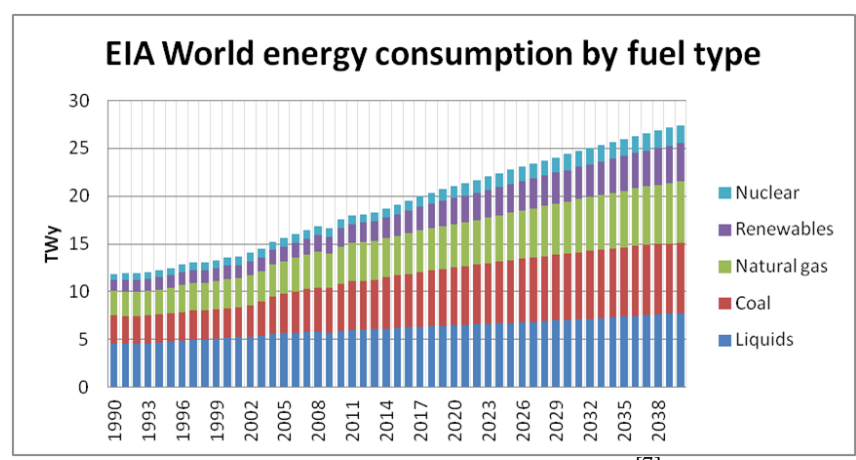

Figure 2: World Energy needs ${ }^{[7]}$

Although the use of renewable energy is expected to increase by a great deal by 2040 , it is also speculated that fossil fuels will still be in use and in fact the consumption will considerably increase. This will not only lead to depletion of reserves but also increases the amount of greenhouse gases in the atmosphere ultimately increasing the average global temperature.

Even though this looks catastrophic, innovations will keep popping up proposing various effective methods to harness other sources of energy. Also, the technology will certainly go to new heights where our lives would be made simple with minimal damage to our planet.

\section{CONCLUSION}

The experimental results obtained show that there is an increase in mileage and therefore, the thermal efficiency of the IC engine. Although this increase only corresponds to around $2-3 \%$, it can be increased a little further by using other techniques like variable valve timing, charge exchange work etc.

The improvement in efficiency of the engines of today may very well be one of the first steps towards further developments and revolutions in the field of energy management which may go from effective management of fossil fuels to the full-time usage of renewable resources leading us to a cleaner and greener future.

\section{REFERENCES}

[1] http://cdiac.ornl.gov/trends/emis/tre_ind.html

[2] https://en.wikipedia.org/wiki/Air_preheater

[3] http://www.thomasnet.com/about/shell-tube-heatexchangers-26641001.html

[4] https://en.wikipedia.org/wiki/Water_vapor

[5] http://www.ustudy.in/node/7902

[6] http://www.treehugger.com/fossil-fuels/world-coursebe-powered-85-fossil-fuels-2050.html 
[7] www.stratosolar.com/2050-world-energy-sankeydiagram.html

[8] British Electricity International (1991). Modern Power Station Practice: incorporating modern power system practice (3rd Edition (12 volume set) Ed.). Pergamon. ISBN 0-08-040510-X.

[9] http://pacificenvironment.org/energy-fossil-fuels

[10] http://www.biomassenergycentre.org.uk/portal/page?_p ageid=76,539186\&_dad=portal\&_schema=PORTAL 